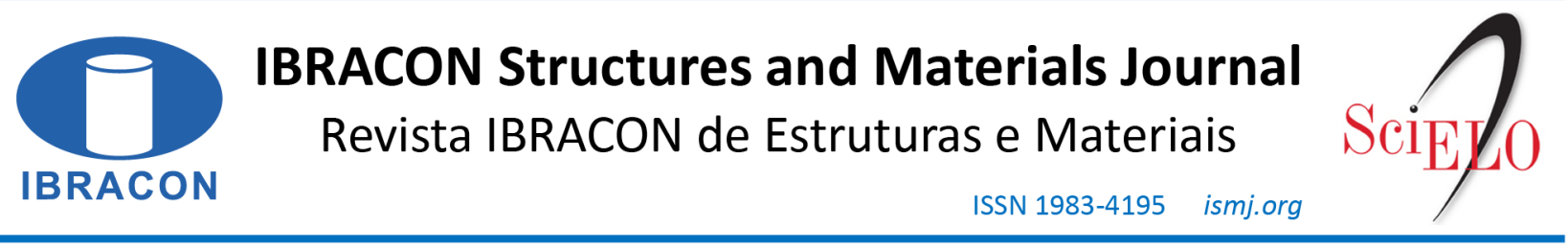

ORIGINAL ARTICLE

\title{
Metal magnesium industry waste for partial replacement of Portland cement
}

\section{Rejeito da indústria de magnésio metálico para substituição parcial do cimento Portland}

\author{
Maysa Lorena Figueiredo Martins ${ }^{\mathrm{a}}$ \\ Richard Rodrigues Barreto ${ }^{\mathrm{b}}$ (iD \\ Paulo Roberto Ribeiro Soares Junior ${ }^{\mathrm{c}}$ (B) \\ Ivete Peixoto Pinheiro ${ }^{\mathrm{b}}$ \\ Augusto Cesar da Silva Bezerra ${ }^{\mathrm{d}}$
}

${ }^{a}$ Centro Federal de Educação Tecnológica de Minas Gerais - CEFET-MG, Programa de Pós-graduação em Engenharia de Materiais, Belo Horizonte, MG, Brasil

${ }^{\mathrm{b}}$ Centro Federal de Educação Tecnológica de Minas Gerais - CEFET-MG, Departamento de Engenharia de Materiais, Belo Horizonte, MG, Brasil ${ }^{\mathrm{c}}$ Centro Federal de Educação Tecnológica de Minas Gerais - CEFET-MG, Programa de Pós-graduação em Engenharia Civil, Belo Horizonte, MG, Brasil ${ }^{\mathrm{d} C e n t r o ~ F e d e r a l ~ d e ~ E d u c a c ̧ a ̃ o ~ T e c n o l o ́ g i c a ~ d e ~ M i n a s ~ G e r a i s ~-~ C E F E T-M G, ~ D e p a r t a m e n t o ~ d e ~ E n g e n h a r i a ~ d e ~ T r a n s p o r t e s, ~ B e l o ~ H o r i z o n t e, ~ M G, ~ B r a s i l ~}$

Received 01 July 2019

Accepted 07 May 2020

\begin{abstract}
The high demand for concrete has triggered studies on the mitigation of Portland cement production impacts, such as greenhouse gas emissions and energy demands, in addition to enabling cost reduction. Partial replacement of cement with other materials has been employed as an alternative to minimize the damage caused by the cement industry. In this regard, it is necessary to use materials that efficiently replace cement clinker. This study uses waste generated from the production of metallic magnesium as a partial replacement for Portland cement. The substitution is aimed at reducing the amount of clinker used, as its production necessitates high energy consumption and results in emission of large quantities of $\mathrm{CO}_{2}$ into the atmosphere. The tailings were characterized via X-ray fluorescence (XRF), X-ray diffraction (XRD), scanning electron microscopy (SEM), and granulometric analysis. For evaluating the mechanical behavior and porosity, $25 \%$ of the cement (by mass) was replaced with tailings, and the resulting composite was molded into cylindrical specimens. After curing for 28 and 91 days, all specimens underwent compression testing. The results of the physical characterization showed that more than $65 \%$ of the tailing grain was lesser than $45 \mu \mathrm{m}$ in size, which contributes to the packaging effect. In terms of the chemical and mineralogical composition, the tailing had high levels of calcium, and the predominant phases could be identified. The compressive strength of the mortar with substitution was higher than $40 \mathrm{MPa}$. The convergence observed between the results of the different characterization techniques demonstrates the efficiency of using the waste as a supplementary cementitious material.
\end{abstract}

Keywords: cementitious composite, industrial reject, mechanical behavior, filler effect.

Resumo: A alta demanda por concreto faz com que estudos sejam desenvolvidos para amenizar os impactos causados pela produção do cimento Portland, como emissões de gases do efeito estufa e demanda energética, além de viabilizar a redução de custos. A utilização de materiais em substituição parcial do cimento vem sendo empregada como alternativa para minimizar os danos causados pela indústria do cimento. Nesse escopo, se faz necessário utilizar materiais que consigam substituir de maneira eficiente o clínquer de cimento. $\mathrm{O}$ presente trabalho utilizou o rejeito resultante da produção de magnésio metálico como substituição parcial do cimento Portland. A substituição visa diminuir a quantidade de clínquer utilizada, tendo em vista que sua produção requer um elevado consumo de energia e emite grandes quantidades de $\mathrm{CO}_{2}$ na atmosfera. A caracterização do rejeito foi feita por meio de fluorescência de raios X (FRX), difração de raios X (DRX), microscopia eletrônica de varredura (MEV) e análise granulométrica. Com intuito de avaliar o comportamento

Corresponding author: Maysa Lorena Figueiredo Martins. E-mail: maysa.Ifm@gmail.com

Financial support: This work was supported by the Minas Gerais State Research Foundation (FAPEMIG) [grant number APQ-03739-16]; and the Brazilian Federal Agency for Support and Evaluation of Graduate Education (CAPES) [grant number 001].

Conflict of interest: Nothing to declare. 
mecânico e a porosidade, a dosagem do compósito resultante foi realizada com substituição parcial do cimento pelo rejeito no teor de $25 \%$ em massa, e foram moldados corpos de prova cilíndricos. Após a cura de 28 e 91 dias, todos os corpos de prova foram ensaiados à compressão. Os resultados da caracterização física mostraram que mais de $65 \%$ dos grãos do rejeito são menores que $45 \mu \mathrm{m}$, o que contribui para o efeito de empacotamento. Quanto à composição química e mineralógica, o rejeito possui altos teores de cálcio e foi possível identificar as fases predominantes. A resistência mecânica à compressão da argamassa com substituição apresentou valores superiores a $40 \mathrm{MPa}$. A convergência entre os resultados de diferentes técnicas de caracterização evidencia a eficiência do rejeito para uso como material cimentício suplementar.

Palavras-chave: compósito cimentício, rejeito industrial, comportamento mecânico, efeito filer.

How to cite: M. L. F. Martins, R. R. Barreto, P. R. R. Soares Junior, I. P Pinheiro, and A. C. S. Bezerra, "Metal magnesium industry waste for partial replacement of Portland cement," Rev. IBRACON Estrut. Mater., vol. 13, no. 6, e13611, 2020, https://doi.org/10.1590/S1983-41952020000600011

\section{INTRODUCTION}

Climate change is directly linked to greenhouse gas concentration, which modifies the average temperature of the planet; in recent years, this has increased. Current climate change is correlated with anthropogenic activities and is considered one of the most significant problems of humanity in the current century, compromising natural resources and life. Among greenhouse gases, $\mathrm{CO}_{2}$ has a relatively high global warming potential, which makes it predominantly responsible for climate change [1], [2].

The main emission sources of polluting gases are the burning of fossil fuels and industrial processes. It is estimated that the cement industry is responsible for up to $7 \%$ of global carbon dioxide emissions, as cement is the most consumed material. Significant $\mathrm{CO}_{2}$ emissions are related to population and economic growth, which requires more prominent and better structures and thus the demand for concrete is growing exponentially; it is estimated that the worldwide demand for concrete will reach $66.3 \mathrm{Gt}$ by 2022. As a result, $\mathrm{CO}_{2}$ emission rates are increasing, along with the demand for concrete. The decarbonization of limestone for the formation of silicates and aluminates in the clinker releases approximately $0.53 \mathrm{t}$ of $\mathrm{CO}_{2}$ per ton of clinker. Decarbonization contributes to approximately $60 \%$ of the total $\mathrm{CO}_{2}$ emission in cement industries [3]-[6].

Clinker production is the main cause of high $\mathrm{CO}_{2}$ emission levels owing to the need for high temperatures to burn the raw material under oxidizing conditions and calcinate it. The clinker process occurs at high temperatures of $1400-$ $1500{ }^{\circ} \mathrm{C}$, at which the reaction of calcium oxide with silica, alumina, and iron oxide occurs; this forms silicates, aluminates, and iron aluminates. The final stage in the process is to grind the clinker together with additives; it is thus vital to research new technological solutions to control $\mathrm{CO}_{2}$ emissions and energy expenditure [7]-[9].

Among the materials already used to partially replace cement and subsequently decrease the amount of clinker used, silica fume, volcanic ash, and granulated slag from the kiln are notable. Research indicates that industrial waste presents a high potential for substitution, mainly owing to its availability and physicochemical properties [10]-[12].

Noteworthy partial clinker replacements include alkali-activated binders and binders based on reactive calcium silicates, magnesium oxides, precipitated calcium carbonates, and phosphates. Studies have demonstrated the significant feasibility of incorporating various cementitious materials into the clinker to produce more sustainable binders, preserving performance. The consumption of fly ash currently represents $70 \%$ of the volume of supplementary cement materials, totaling $\$ 75$ billion in sales, and it is estimated to reach $\$ 98$ billion in 2020 as a result of the high demand for materials that can partially replace clinker, reducing energy consumption and the emission of carbon dioxide. Industrial by-products are potential materials for partial replacement; these are environmentally viable, and they are considered as waste owing to their low cost [13]-[15]. In recent decades, some types of binders based on magnesium silicates, amorphous calcium carbonates, and phosphates have been used in the production of cementitious materials, encouraging interest in the use of industrial residues of mineral and vegetal origin. Studies show significant results regarding the mechanical performance and durability of cementitious materials composed of industrial by-products [16]-[25].

\subsection{Justification}

The use of materials as a substitute for clinker is gaining ground in cement production. The percentage of cement replacement is growing as it contributes to lower $\mathrm{CO}_{2}$ emission and reduces energy expenditure, without impairing the performance of composites. At present, there is a search for materials that meet the ideal requirements for partially replacing cement. Studies on industrial waste indicate that they are a feasible substitute material. Hence, the focus of this study was to investigate the chemical, physical, and microstructural characteristics of tailings from the metal magnesium industry as a partial substitute for Portland cement, in addition to the compressive strength and porosity of the composite. Finally, this study established the efficacy of the waste as a new cementitious material. 


\section{MATERIALS AND EXPERIMENTAL PROGRAM}

The waste used is a by-product of the metal magnesium industry, where dolomite is calcined in a rotary kiln as a raw material, mixed with silicon iron, and then processed under high vacuum - a process referred to as silicotherm. Resultantly, crude magnesium appears in the form of crystals, which are then melted and refined until reaching the characteristics of the final product, metallic magnesium, according to Rima Industrial S.A. The amount of by-product generated by the unit in Bocaiuva/MG is approximately $120 \mathrm{t} / \mathrm{month}$. The waste was characterized and its composition quantified, following which it was used to partially replace Portland cement in the production of mortar. The tailings are light in color and have fine granulometry.

The tailings sample was used as received, without processing, owing to its small particle size and previous calcination performed in the industry. The tailings were characterized via X-ray fluorescence (XRF), X-ray diffraction (XRD), scanning electron microscopy (SEM), particle size analysis, and laser particle size. The XRF was performed using the ZSX/Primus II spectrometer, manufactured by RIGAKU, with the use of pressed powder tablets. The XRD results were obtained using the SHIMADZU diffractometer, model XRD-7000, with the emission of $\mathrm{Cu}$ k-alpha radiation $(40 \mathrm{kV} / 30 \mathrm{~mA})$, under a $2 \theta$ scan of $40^{\circ}$ and $90^{\circ}$ and a reading of $2^{\circ}$ per min. The SEM images were captured using a Hitachi low-vacuum scanning electron microscope, model TM3000, with an electron acceleration of $15 \mathrm{kV}$. The granulometry was verified using the Cilas 1090 Laser Particle Size Analyzer laser granulometer, with obscuration of around 13-18\%.

\subsection{Obtaining the specimens}

In the process of molding the specimens, Portland cement with a high initial strength was used as per the NBR 16697 standard [26]; containing a low percentage of additions, the cement was composed of clinker with calcium sulfate (90 to 100\%) and carbonate material (0 to 10\%). The choice of cement is related to the low levels of carbonate materials, i.e., the one that best approaches a cement that contains only the clinker. This alternative allows verification of the substitution efficiency.

The aggregate used was quartz sand, with four different granulometric fractions, according to NBR 7214 [27]. The local supply system supplied the mixing water. The replacement adopted was $25 \%$ by weight of Portland cement for industrial waste. The replacement content was chosen to verify the upper limit of the NBR 16697 standard [26], which establishes strength classes for Portland cement. This allowed for evaluation of the replacement at the maximum value, in consideration of carbonate materials.

The mortar was established using NBR 7215 and in consideration of previous studies [28]-[30]. A 1:3 ratio between binder and aggregates was defined, with a water/binder factor of 0.48 , as presented in Table 1 . Two types of cementitious composites were fabricated; the first was a reference using Portland cement without replacement and the second had $25 \%$ cement replacement by tailings. The duly quantified materials, according to the established line, passed through the mechanical mixing process and were placed in cylindrical steel molds, with a diameter of $50 \mathrm{~mm}$ and a height of $100 \mathrm{~mm}$, according to the NBR 7215 standard [30].

Table 1. Established proportions for molding

\begin{tabular}{ccccc}
\hline & \multicolumn{2}{c}{ Proportions in weight (kg) } & Water/binder factor \\
\cline { 2 - 3 } & $\begin{array}{c}\text { Portland } \\
\text { cement }\end{array}$ & Tailing & Sand & \\
\hline Composition I (Reference) & 1.0 & - & 3.0 & 0.48 \\
\hline Composition II (Replacement) & 0.75 & 0.25 & 3.0 & 0.48 \\
\hline
\end{tabular}

After undergoing 24 hours of molding, the specimens were placed in a submerged cure in water saturated with calcium hydroxide for a period of 28 and 91 days. The compressive strength test was performed at 28 and 91 days, with four specimens for each line by age.

The results of the same trait were averaged; if any result showed a deviation more significant than $6 \%$, the furthest value was excluded and the average recalculated. If the deviation was more significant than $6 \%$, the test was to be repeated; however, this did not happen during this study. For determining the water absorption, the same number of specimens, test age, and procedure for eliminating results were used. 


\subsection{Mechanical testing and water absorption}

The compression test was performed after 28 and 91 days of curing, using universal mechanical testing equipment, with a capacity of $300 \mathrm{kN}$. The specimens were inserted into the equipment at a constant loading rate of $0.25 \mathrm{MPa} / \mathrm{s}$ to promote an almost-static condition for the test and to facilitate consistency of the results. The accommodation of stresses on the upper and lower faces of the specimens was performed with the use of neoprene discs, coupled in metallic supports.

The water absorption test aims to verify the porosity present in the specimens, identifying the presence of pores in the material. The test was conducted using a hydrostatic scale, with an attached basket to hold the sample during weighing; this was inserted into a container containing water. The specimens were weighed under three conditions: (i) saturated, (ii) submerged in water, and (iii) dried for 24 hours, in an electric oven at a temperature of $100{ }^{\circ} \mathrm{C}$, after the mass constancy was verified. Porosity was established by the relationship between permeable pore volume and total volume; the difference between the mass of the saturated and dry specimen was divided by the difference between the mass of the saturated and submerged specimen and the result multiplied by 100 to obtain the percentage of voids.

\section{RESULTS AND DISCUSSIONS}

\subsection{Chemical and mineralogical}

The X-ray fluorescence test allowed the chemical composition of the waste to be determined. The results are presented in terms of oxides (Table 2) owing to the semi-quantitative analysis. As the waste is obtained from the metal magnesium industry, the presence of magnesium oxide, silicon oxide, and calcium oxide was expected due to the silicothermal process involved in obtaining magnesium.

Table 2. Chemical composition of tailings.

\begin{tabular}{ccccccccc}
\hline Oxides & $\mathrm{Na}_{2} \mathbf{O}$ & $\mathbf{M g O}$ & $\mathbf{A l}_{\mathbf{2}} \mathbf{O}_{3}$ & $\mathrm{SiO}_{2}$ & $\mathbf{P}_{2} \mathbf{O}_{5}$ & $\mathbf{S O}_{3}$ & $\mathbf{C a O}_{2}$ & $\mathbf{F e}_{2} \mathbf{O}_{3}$ \\
\hline$\%$ & 0.04 & 6.9 & 0.2 & 29.5 & 0.04 & 0.15 & 59.7 & 3.2 \\
\hline
\end{tabular}

The XRD analysis (Figure 1) allowed for the detection of the predominant mineralogical phases, the mineral Calcio-Olivine (COD 9012681), indicative of the polymorphism of the structures of Ca2.SiO4 and the periclase (COD 9005513). Calcium silicate is present owing to the calcination processes, whereas the presence of periclase or periclase is expected as it is a material derived from dolomite; this also justifies the presence of $\mathrm{MgO}$ in the chemical analysis of the material.

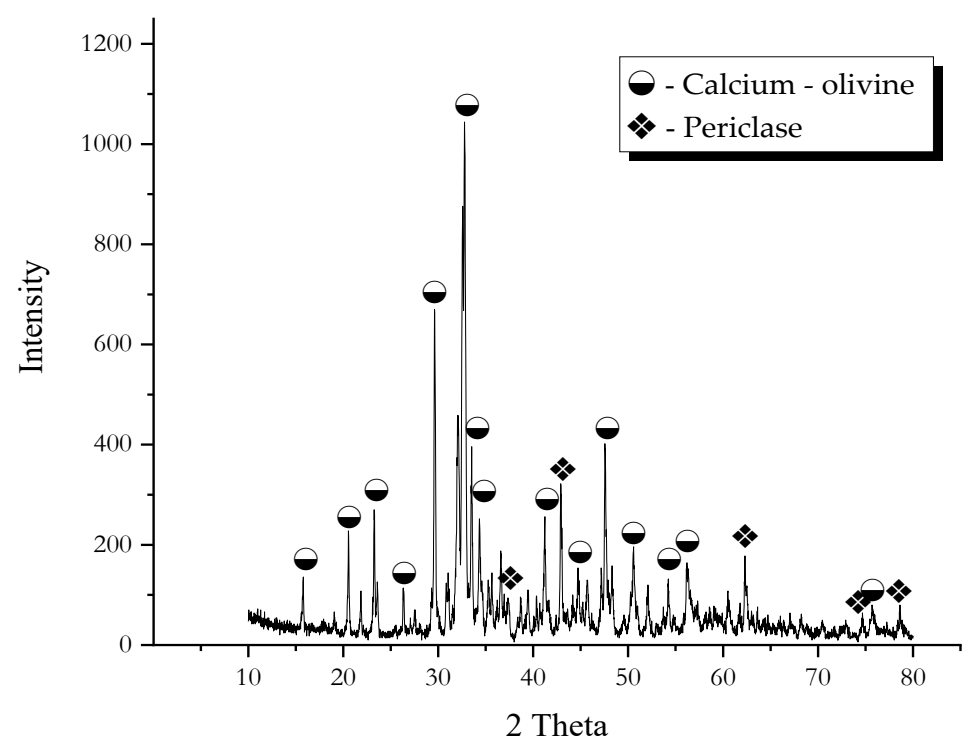

Figure 1. Diffractogram of tailings from the production of metallic magnesium. 


\subsection{Granulometry}

The results of the laser granulometry indicate that $90 \%$ of the material had a granulometry smaller than $39.76 \mu \mathrm{m}$, which confirms the visual analysis and the fine, powdery characteristic of the residue; this can be confirmed by Figure 2, which presents the particle distribution as a histogram of the cumulative passing.

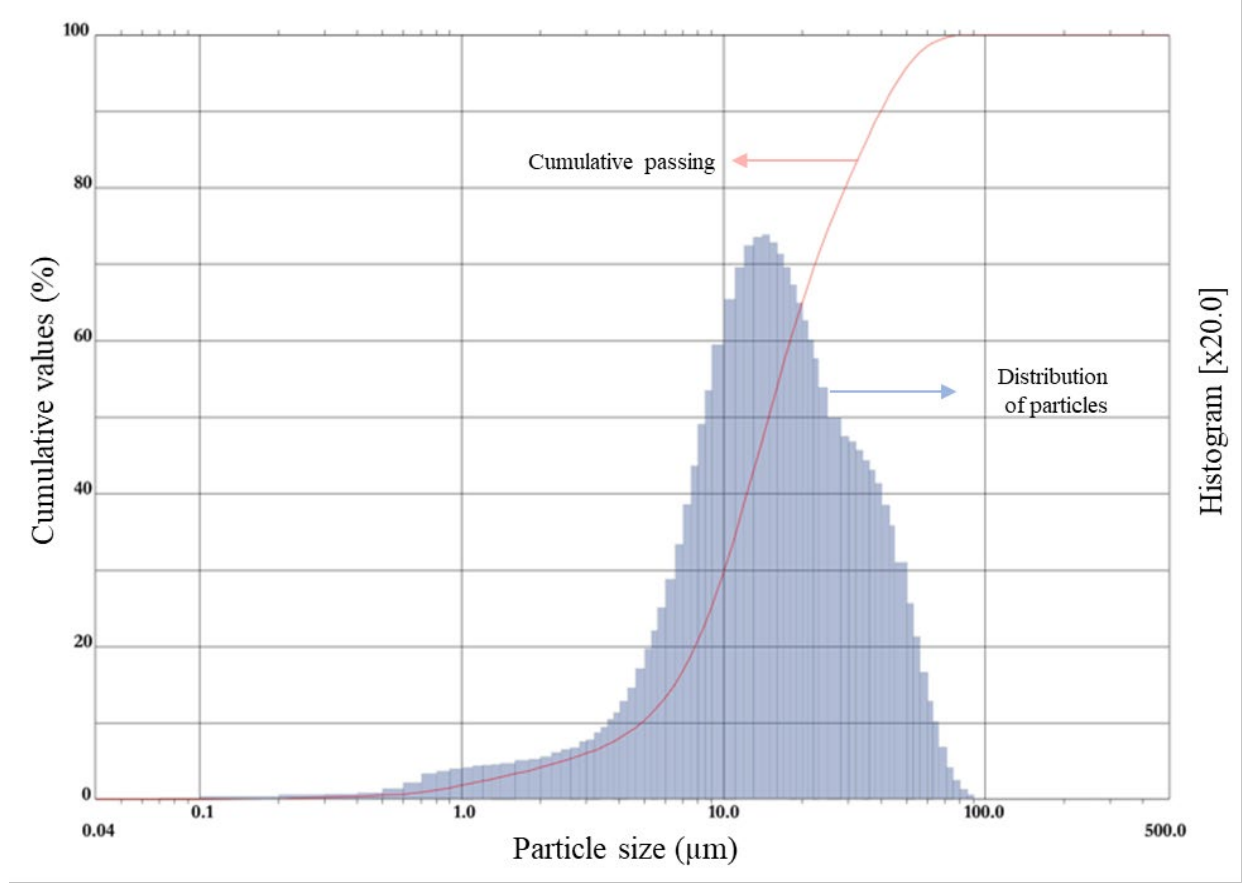

Figure 2. Laser particle size of the tailings.

Materials that present a very fine inert mineral load contribute to the density and strength of the cementitious composite owing to the finer fraction, which contributes to the hardening and filling of the voids; known as the filler effect. The effect occurs due to adhesion of the binder paste in the particulate interface, favoring the chemical and mechanical resistance of the composites, and decreasing the porosity. Adding materials with a filler effect improves performance, reducing voids and permeability, and increasing workability and strength [31]-[33].

\subsection{Microstructural research}

SEM allows observation of the morphology and topography and helps to elucidate the physical characteristics of the material under study [34]-[37]. The micrographs obtained via SEM (Figure 3) allowed for observation of the morphological characteristics of the tailings, which comprise micrometric particles with an approximate variation of 3 $80 \mu \mathrm{m}$; these particles account for the majority of fragments with dimensions around $19 \mu \mathrm{m}$, which is in agreement with the image scale generated via SEM.

In general, it is observed that the particles are heterogeneous, considering the various existing forms. The grains have irregular geometry (Figure 3a), features with a rough surface (Figure 3b), are porous (Figure 3c), and smooth (Figure 3d); observed according to the increase in resolution of 500x to $2 \mathrm{~K}$ in Figure 3. Lamellar structures are revealed at some points, indicating the presence of kaolinite.

\subsection{Mechanical behavior}

The compression test defines the ability of the material to withstand the forces applied directly. Research on using cementitious materials as a substitute for cement has evaluated the strength over time, and a strength of approximately 32 - $45 \mathrm{MPa}$ has been determined [38]-[41]. The compression test was performed on reference specimens (without replacement) and specimens with a $25 \%$ replacement of cement by tailings. The results showed that the two types of 
materials were above $40 \mathrm{MPa}$ at 28 days, a satisfactory result when compared to the literature. There was also an increase in resistance over the healing ages (Figure 4).
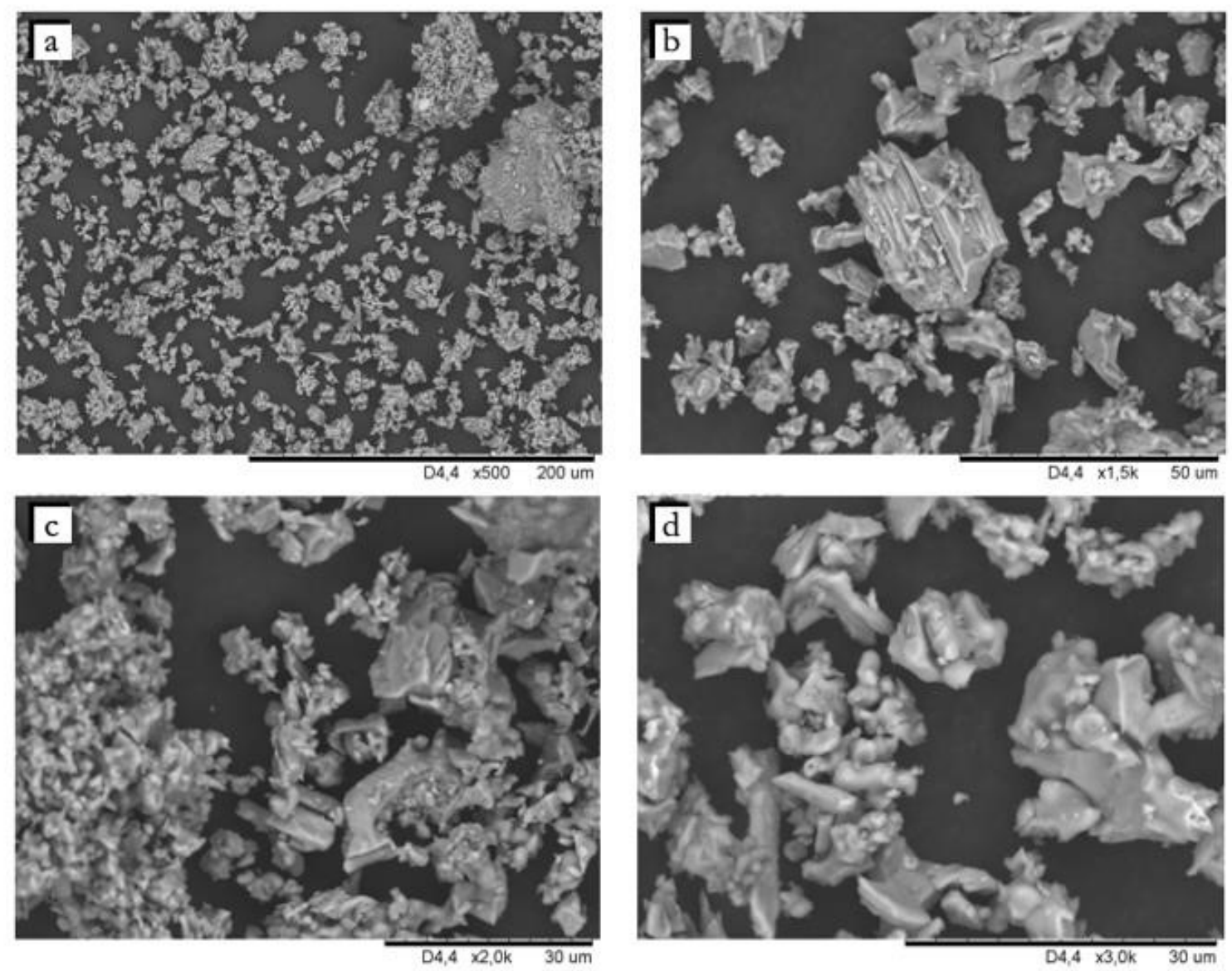

Figure 3. Tailing images obtained by SEM with different resolutions to observe the morphology of the material under study. (a) $500 \mathrm{x}$ resolution, (b) $1.5 \mathrm{~K}$ resolution, (c) $2.0 \mathrm{~K}$ resolution, and (d) resolution of $3.0 \mathrm{~K}$.

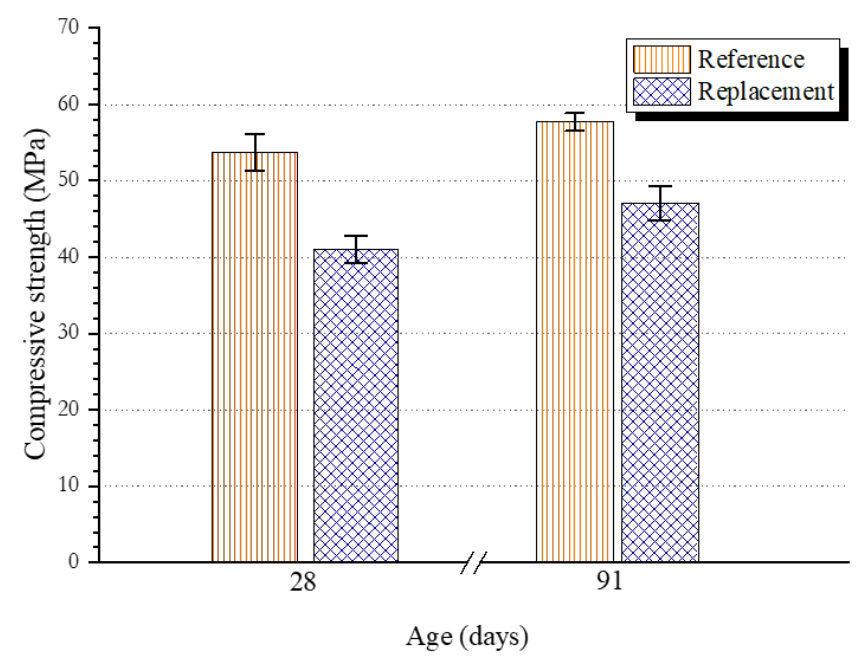

Figure 4. Results of the compressive strength test at 28 and 91 days. 
The substituted material showed results above $40 \mathrm{MPa}$ in the first 28 days and an increase in strength of $14.63 \%$ at 91 days; these values are higher than those established by NBR 16697 [26]. This result demonstrates that the material was efficient in partially replacing Portland cement. The variation in results, considering the deviation for both 28 and 91 days, demonstrated that the values obtained follow the values established in the norm and are compatible with similar studies [26], [38]-[41].

\subsection{Porosity}

The water absorption test demonstrated that the porosity of the replaced material decreased in the first 28 days when compared to the reference. At 91 days, the porosity values are close, as shown in Figure 5.

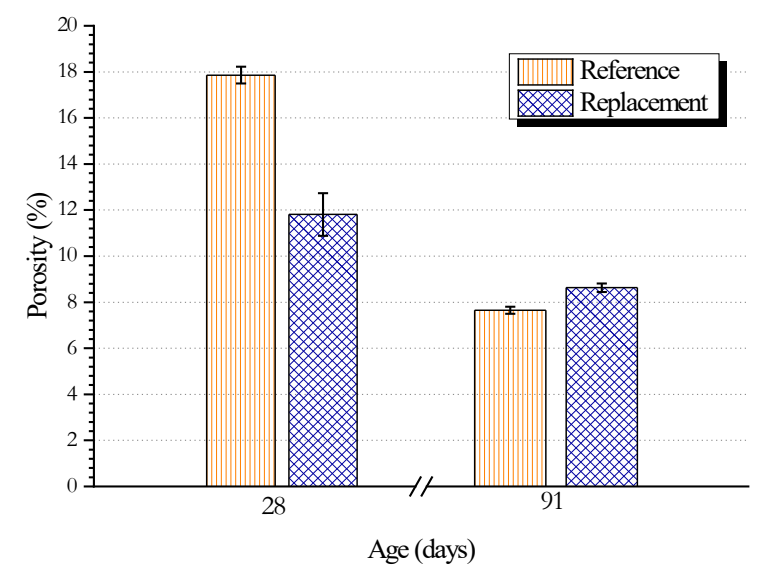

Figure 5. Results of the water absorption test after 28 and 91 days of curing.

The smaller number of voids indicates the occurrence of a filler effect, caused by the fine granulometry of the residue; this contributed to improved filling of the spaces between the mortar constituents and, consequently, the production of a material with less porosity. Furthermore, the formation of new cement hydration products and additions is assessed over time, with denser and more consistent structures filling the voids.

At 28 days, the variation in results was more significant than at 91 days, for the two evaluated traits. Despite the higher deviation at 28 days, the trace with residue showed a considerably lower number of voids than that of the reference trace. In contrast to the initial occurrences, where grain growth and emptying takes place at an accelerated rate, grain growth becomes stable and there are fewer voids after a period of time [42]. Thus, at 91 days, the deviation is significantly less than at 28 days.

\section{CONCLUSIONS}

The studies and tests carried out indicate the feasibility of using waste from the metal magnesium industry as a partial substitute for Portland cement. The material under analysis demonstrated chemical, structural, morphological, and granulometric characteristics, which contributed to the performance of the cementitious composite. In addition, the potential to promote the filler effect was evident owing to the fine granulometry, decreasing the porosity, and promoting the densification of the cement matrix. The mechanical behavior results demonstrated values higher than those established by the norm and in analogous studies. In this scope, the evaluated waste is eligible for partial replacement of Portland cement, contributing to the production of binders with less environmental impact, reducing $\mathrm{CO}_{2}$ emissions, and reducing energy demand, with a view to sustainable development.

\section{ACKNOWLEDGEMENTS}

This work was supported by the Minas Gerais State Research Foundation (FAPEMIG) [grant numbers APQ-03739-16], the Brazilian Federal Agency for Support and Evaluation of Graduate Education (CAPES) [grant number 001], and Rima Industrial S.A. via donation of research material. 


\section{REFERENCES}

[1] N. J. L. Lenssen et al., "Improvements in the uncertainty model in the Goddard Institute for Space Studies Surface Temperature (GISTEMP) analysis," J. Geophys. Res. Atmos., vol. 124, 2019.

[2] D. Krekel, R. C. Samsun, R. Peters, and D. Stolten, "The separation of $\mathrm{CO}_{2}$ from ambient air - a techno-economic assessment," Appl. Energy, vol. 218, pp. 361-381, 2018., http://dx.doi.org/10.1016/j.apenergy.2018.02.144.

[3] K. L. Scrivener, V. M. John, and E. M. Gartner, "Eco-efficient cements: potential economically viable solutions for a low-CO cement-based materials industry," Cement Concr. Res., vol. 114, pp. 2-26, 2018.

[4] A. Nazari, J. G. Sanjayan, and J. S. J. Van Deventer, "Progress in the adoption of geopolymer cement," in A. Nazari, Ed., Handbook of Low Carbon Concrete. Amsterdam: Academic Press, 2017, pp. 217-262.

[5] E. Benhelal, G. Zahedi, E. Shamsaei, and A. Bahadori, "Global strategies and potentials to curb CO2emissions in cement industry," J. Clean. Prod., vol. 51, pp. 142-161, 2013.

[6] L. Evangelista and J. D. Silvestre, "Equivalent functional unit in recycled aggregate concrete," in J. Brito and F. Agrela, Eds., New Trends in Eco-efficient and Recycled Concrete. Duxford: Elsevier, 2019, pp. 293-327.

[7] N. Mahasenan, S. Smith, and K. Humphreys, "The cement industry and global climate changecurrent and potential future cement industry $\mathrm{CO}_{2}$ emissions," in Greenh. Gas Control Technol. 6th Int. Conf., 2003, pp. 995-1000.

[8] R. Kajaste and M. Hurme, "Cement industry greenhouse gas emissions e management options and abatement cost," J. Clean. Prod., vol. 112, pp. 4041-4052, 2016.

[9] P. Singh, "Waste handling in liquid absorbent-based post-combustion capture processes," in Absorption-Based Post-combustion Capture of Carbon Dioxide, P. H. M. Feron, Ed., Duxford: Woodhead Publishing, 2016, pp. 505-517.

[10] J. Armengaud, M. Cyr, G. Casaux-Ginestet, and B. Husson, "Durability of dry-mix shotcrete using supplementary cementitious materials," Constr. Build. Mater., vol. 190, pp. 1-12, 2018.

[11] M. Wu, Y. Zhang, G. Liu, Z. Wu, Y. Yang, and W. Sun, "Experimental study on the performance of lime-based low carbon cementitious materials," Constr. Build. Mater., vol. 168, pp. 780-793, 2018.

[12] S. Ruan and C. Unluer, "Comparative life cycle assessment of reactive MgO and Portland cement production," J. Clean. Prod., vol. 137, pp. 258-273, 2016.

[13] E. Gartner and T. Sui, "Alternative cement clinkers," Cement Concr. Res., vol. 114, pp. 27-39, 2018.

[14] P. C. Aitcin, "Supplementary cementitious materials and blended cements," in Science and Technology of Concrete Admixtures, P. C. Aïtcin and R. J. Flatt, Eds., Cambridge: Woodhead Publishing, 2016, pp. 53-73.

[15] L. L. Sutter and D. P. Bentz, "Assessing ash quality and performance," in Coal Combustion Products (CCP's) - Characteristics, Utilization and Beneficiation, T. Robl, A. Oberlink, and R. Jones, Eds., Oxford: Woodhead Publishing, 2017, pp. $225-254$.

[16] M. Frías, R. Vigil de la Villa, R. García, S. Martínez, E. Villar, and I. Vegas, "Effect of a high content in activated carbon waste on low clinker cement microstructure and properties," Constr. Build. Mater., vol. 184, pp. 11-19, 2018.

[17] S. Kim, A. Hanif, and I. Jang, "Incorporating Liquid Crystal Display (LCD) glass waste as Supplementary Cementing Material (SCM) in cement mortars - rationale based on hydration, durability, and pore characteristics," Materials, vol. 11, no. 12, pp. 2538, 2018.

[18] Y. C. Li et al., "Utilization of red mud and $\mathrm{Pb} / \mathrm{Zn}$ smelter waste for the synthesis of a red mud-based cementitious material," $J$. Hazard. Mater., vol. 344, pp. 343-349, 2018.

[19] G. Medina, I. F. Sáez del Bosque, M. Frías, M. I. Sánchez de Rojas, and C. Medina, "Granite quarry waste as a future eco-efficient supplementary cementitious material (SCM): Scientific and technical considerations," J. Clean. Prod., vol. 148, pp. 467-476, 2017.

[20] M. Nasir and W. Al-Kutti, "Performance of date palm ash as a cementitious material by evaluating strength, durability, and characterization," Buildings, vol. 9, no. 1, pp. 6, 2018.

[21] A. A. Ramezanianpour, R. Mousavi, M. Kalhori, J. Sobhani, and M. Najimi, "Micro and macro level properties of natural zeolite contained concretes," Constr. Build. Mater., vol. 101, pp. 347-358, 2015.

[22] K. Ramakrishnan, G. Pugazhmani, R. Sripragadeesh, D. Muthu, and C. Venkatasubramanian, "Experimental study on the mechanical and durability properties of concrete with waste glass powder and ground granulated blast furnace slag as supplementary cementitious materials," Constr. Build. Mater., vol. 156, pp. 739-749, 2017.

[23] M. A. A. Sherir, K. M. A. Hossain, and M. Lachemi, "Self-healing and expansion characteristics of cementitious composites with high volume fly ash and MgO-type expansive agent," Constr. Build. Mater., vol. 127, pp. 80-92, 2016.

[24] M. Sumesh, U. J. Alengaram, M. Z. Jumaat, and K. H. Mo, "Microstructural and strength characteristics of high-strength mortar using nontraditional supplementary cementitious materials," J. Mater. Civ. Eng., vol. 31, no. 4, pp. 4019017, 2019.

[25] H. Wang, H. Li, X. Liang, H. Zhou, N. Xie, and Z. Dai, "Investigation on the mechanical properties and environmental impacts of pervious concrete containing fly ash based on the cement-aggregate ratio," Constr. Build. Mater., vol. 202, pp. 387-395, 2019.

[26] Associação Brasileira de Normas Técnicas, Cimento Portland-Requisitos, NBR16697, 2018. 
[27] Associação Brasileira de Normas Técnicas, Areia Normal para Ensaio de Cimento - Especificação, NBR 7214, 2015 , pp. 4.

[28] P. Mehta and P. Monteiro, Concreto: Microestrutura, Propriedades e Materiais. São Paulo: IBRACON, 2014.

[29] P. Helene and B. F. Tutikian, "Dosagem dos concretos de cimento Portland,” in Concreto: Ciência e Tecnologia, G. C. Isaia, Ed., São Paulo: IBRACON, 2011.

[30] Associação Brasileira de Normas Técnicas, Cimento Portland - Determinação da Resistência à Compressão, NBR 7215, 2019.

[31] İ. B. Topçu and A. Uğurlu, "Effect of the use of mineral filler on the properties of concrete," Cement Concr. Res., vol. 33, no. 7, pp. 1071-1075, 2003.

[32] J. G. Speight, “Asphalt technology,” in Asphalt Materials Science and Technology. Amsterdam: Elsevier, 2016, pp. 361-408.

[33] S. Ebnesajjad and S. Ebnesajjad, "Adhesion promoters," in Surface Treatment of Materials for Adhesion Bonding. Amsterdam: William Andrew, 2014, pp. 301-329.

[34] Z. Liu et al., "A review of fine structures of nanoporous materials as evidenced by microscopic methods," Microscopy, vol. 62, no. 1, pp. 109-146, 2013.

[35] S. Stevens et al., "An appraisal of high resolution scanning electron microscopy applied to porous materials," JEOL News, vol. 44, pp. 17-22, 2009.

[36] B. W. Jo, C. H. Kim, and J. H. Lim, "Characteristics of cement mortar with nano-SiO 2 particles," ACI Mater. J., vol. 104, pp. 404407, 2007.

[37] A. Sharif, "Review on advances in nanoscale microscopy in cement research," Micron, vol. 80, pp. 45-58, 2016.

[38] L. R. Steiner, A. M. Bernardin, and F. Pelisser, "Effectiveness of ceramic tile polishing residues as supplementary cementitious materials for cement mortars," Sustain. Mater. Technol., vol. 4, pp. 30-35, 2015.

[39] L. Rodier and H. Savastano Jr., "Use of glass powder residue for the elaboration of eco-efficient cementitious materials," J. Clean. Prod., vol. 184, pp. 333-341, 2018.

[40] P. R. Matos, L. R. Prudêncio Jr., A. L. Oliveira, F. Pelisser, and P. J. P. Gleize, "Use of porcelain polishing residue as a supplementary cimentitious material in self-compacting concrete," Constr. Build. Mater., vol. 193, pp. 623-630, 2018.

[41] D. Dodoo-Arhin, R. A. Nuamah, B. Agyei-Tuffour, D. O. Obada, and A. Yaya, "Awaso bauxite red mud-cement based composites: characterization for pavement applications," Case Stud. Constr. Mater., vol. 7, pp. 45-55, 2017.

[42] K. Scrivener, A. Ouzia, P. Juilland, and A. Kunhi Mohamed, "Advances in understanding cement hydration mechanisms," Cement Concr. Res., vol. 124, pp. 105823, 2019.

Author contributions: All authors contributed to the research. M.L.F.M: conceptualization, methodology, investigation, data curation, writing original draft preparation and editing. R.R.B: software and validation. P.R.S.J: conceptualization, methodology, writing - review and editing. I.P.P: funding acquisition, supervision and writing-review. A.C.S.B: conceptualization, methodology, investigation, funding acquisition, supervision, formal analysis and writing - review.

Editors: Fernando Pelisser, José Luiz Antunes de Oliveira e Sousa, Guilherme Aris Parsekian. 